\title{
Responses of microsomal NADPH-cytochrome c reductase activity and cytochrome $P-450$ in digestive glands of Mytilus edulis and Littorina littorea to environmental and experimental exposure to pollutants
}

\author{
D. R. Livingstone \\ Plymouth Marine Laboratory (West Hoe), Prospect Place, The Hoe, Plymouth PL1 3DH, United Kingdom
}

\begin{abstract}
Digestive gland microsomal components were measured during the GEEP Workshop in mussels Mytilus edulis and periwinkles Littorina littorea exposed to different levels of chemical contaminants in an experimental facility (diesel oil/copper mixture) and along a field pollution gradient in Langesundfjord, Norway. Cytochrome P-450 content increased in mussels and periwinkles with experimental exposure and was elevated in mussels from some of the more contaminated field sites. Increases in P-450 content were accompanied by a blue shift in the P- $450 \lambda_{\max }$ suggesting isoenzyme synthesis. NADPH-cytochrome c (P-450) reductase activity increased in mussels and periwinkles with experimental exposure but showed only decreases in the field. The ' 418 ' peak of the P-450 carbon monoxide difference spectrum increased in mussels and periwinkles with both experimental and field contaminant exposure. It is concluded that mussels were affected by organic chemical contamination, and to an extent increasingly so with increasing contamination, but that application of these methods in environmental monitoring is limited by a lack of understanding of the basic nature and function of the molluscan MFO system.
\end{abstract}

\section{INTRODUCTION}

The cytochrome P-450 mono-oxygenase or mixed function oxidase (MFO) system is an apparently universally distributed enzyme system involved in the detoxication and, in some cases, the metabolic activation of foreign organic compounds (xenobiotics), such as polynuclear aromatic hydrocarbons (PAH) (Sato \& Omura 1978). In the common mussel Mytilus edulis it is primarily located in the microsomal fraction (endoplasmic reticulum) of the digestive gland (hepatopancreas) (Livingstone \& Farrar 1984); its presence has been demonstrated or indicated in the same tissue in a number of other bivalve and gastropod species (Livingstone 1985a, Stegeman 1985, Livingstone et al. 1986) including the periwinkle Littorina littorea (Livingstone et al. 1985). Components of the MFO system have been observed to respond (increase) to exposure to hydrocarbons in a number of molluscan species, viz. M. edulis and L. littorea (Livingstone et al.
1985, Livingstone 1987a), cockle Cardium edule (Moore et al. 1987b), oyster drill Thais haemastoma (Livingstone et al. 1986) and mussel Mytilus galloprovincialis (Gilewicz et al. 1984). However, the significance of such changes to the in vivo metabolism and activation of organic xenobiotics is not yet known (Moore et al. 1987a).

Increases in the activities or components of the MFO system have been proposed as a means of identifying or detecting biological impact by organic pollution in the field (Lee et al. 1980, Livingstone 1985b), and a number of successful studies have been carried out with fish (Kurelec et al. 1977, Davies et al. 1984, Stegeman et al. 1986). Bivalve and gastropod molluscs are widely used in environmental monitoring programmes (Goldberg et al. 1978, Moore et al. 1982, Livingstone 1984) and a specific index of impact by organic pollution would be an equally desirable facility for use with these organisms.

Mussels and periwinkles were taken from the field 
contaminant gradient in Langesundfjord and from the experimental exposure to the diesel oil/copper mixture at Solbergstrand, and the responses of the digestive gland MFO system examined in terms of cytochrome P. 450 content and NADPH-cytochrome c (P-450) reductase activity. In addition, the $\lambda_{\max }$ of cytochrome P-450 and the unidentified low wavelength peak $(\approx 418 \mathrm{~nm}$ ) that is observed in the carbon monoxide difference spectrum of dithionite-treated microsomal samples (Livingstone et al. 1985, Moore et al. 1987b) were also quantified. Tissue chemical contamination data for mussels were taken from Klungsøyr et al. (1988) and periwinkles were analysed for 2- and 3-ring PAH compounds.

\section{MATERIAL AND METHODS}

Animal collection and the experimental facility. Mussels Mytilus edulis (4 to $6 \mathrm{~cm}$ length) and periwinkles Littorina littorea (ca $2 \mathrm{~cm}$ size) were collected from Field sites 1 to 4 along the chemical contaminant gradient in Langesundfjord (Site 1 being the reference site), and from the control (C), low (L), medium (M) and high $(\mathrm{H})$ dose exposure conditions in the Solbergstrand experiment (for details see Bakke et al. 1988, Follum \& Moe 1988). Aproximate dosing levels of the latter were L: 6 ppb PAH (fluorescence analysis) and $0.8 \mathrm{ppb} \mathrm{Cu}$; $\mathrm{M}: 32 \mathrm{ppb} \mathrm{PAH}$ and 5 ppb $\mathrm{Cu}_{i} \mathrm{H}$ : $125 \mathrm{ppb} \mathrm{PAH}$ and 20 ppb $\mathrm{Cu}$, with a background of $3 \mathrm{ppb}$ PAH for the $\mathrm{C}$ condition. Animals were exposed for ca $15 \mathrm{wk}$ with the exception of the high-dose mussels which were exposed for $23 \mathrm{~d}$ only, due to total mortality of the mussels originally stocked in the $H$ basin.

Tissue handling, preparation of digestive gland microsomes and biochemical measurements. On arrival of mussels and periwinkles in the laboratory, digestive glands were immediately dissected-out, dampdried, frozen in liquid-nitrogen and stored at $-70^{\circ} \mathrm{C}$ prior to analysis. Pooled tissues of about 6 individuals were used for each sample. Eight samples were taken for each combination of species and condition (field site or mesocosm basin), except for periwinkles from the experimental exposures for which 6 samples were taken.

Microsomes were prepared from the digestive glands by a modification of the method described in Livingstone et al. (1985). Frozen tissue pools were weighed and all subsequent procedures carried out at $4{ }^{\circ} \mathrm{C}$. The tissue was homogenized in a 1:4 tissue weight:buffer volume ratio in $20 \mathrm{mM}$ Tris $-\mathrm{HCl} \mathrm{pH}$ 7.6, containing $0.5 \mathrm{M}$ sucrose, $0.15 \mathrm{M} \mathrm{KCl}, 1 \mathrm{~m} M$ EDTA (ethylenediaminetetraacetic acid), $1 \mathrm{mM}$ DTT (dithiothreitol) and $100 \mu M$ PMSF (phenylmethylsulphonyl fluoride) using an electrically-driven Potter-Elvehjem teflon homogenizer The homogenate was centrifuged at
$500 \times g$ for $30 \mathrm{~min}$, and the resulting supernatant centrifuged at $12000 \times \mathrm{g}$ for $45 \mathrm{~min}$. The $12000 \times \mathrm{g}$ supernatant was centrifuged at $100000 \times \mathrm{g}$ for $90 \mathrm{~min}$ and, after removal of the $100000 \times g$ supernatant, the resulting microsomal pellet was washed by carefully overlayering it with a small volume of microsomal buffer $(20 \mathrm{mM}$ Tris- $\mathrm{HCl}$ pH 7.6 containing $20 \% \mathrm{w} / \mathrm{v}$ glycerol, $1 \mathrm{mMDTT}$ and $1 \mathrm{mMEDTA}$ ) and centrifuging at $12000 \times g$ for $30 \mathrm{~min}$. After removal of the washings the final pellet was resuspended in microsomal buffer to give a total protein concentration of about $10 \mathrm{mg} \mathrm{ml}^{-1}$ (equivalent to a resuspension ratio of the microsomal material from $1 \mathrm{~g}$ wet weight of tissue into $0.5 \mathrm{ml}$ buffer). The microsomal preparations were subdivided into 2 aliquots. One was used immediately for the determination of cytochrome P-450 and the other kept frozen overnight at $-70^{\circ} \mathrm{C}$ prior to the measurement of NADPH-cytochrome $c(\mathrm{P}-450)$ reductase activity and total protein.

Biochemical measurements were carried out on a Pye-Unicam SP8-200 dual-beam recording spectrophotometer, temperature-controlled to $25^{\circ} \mathrm{C}$ and fitted with automatic baseline correction and recorderdampening facilities. Cytochrome P-450 was quantified from the carbon monoxide difference spectrum of sodium dithionite treated samples using an extinction coefficient of $91 \mathrm{mM}^{-1} \mathrm{~cm}^{-1}$ (450 to $490 \mathrm{~nm}$ ) (Estabrook \& Werringloer 1978) as follows: $1.0 \mathrm{ml}$ of $100 \mathrm{mM}$ Tris$\mathrm{HCl} \mathrm{pH} \mathrm{7.6,} 850 \mu \mathrm{l}$ distilled water and $150 \mu \mathrm{l}$ of microsomes were mixed and divided between 2 semimicro cuvettes, carbon monoxide was bubbled (ca 70 bubbles $\mathrm{min}^{-1}$ ) through the sample cuvette and a corrected baseline was run, a few grains of dithionite were added to each cuvette and the spectra scanned several times over about $5 \mathrm{~min}$ using the recorderdampening facility (recorder absorbance scale used was 0.05 or 0.02$)$; $\lambda_{\max }$ of the absorbance peak was determined without use of recorder-dampening. NADPH-cytochrome $c$ reductase activity was measured by the increase in absorbance at $550 \mathrm{~nm}$ as described in Livingstone \& Farrar (1984) using an extinction coefficient of $19.6 \mathrm{~m}^{-1} \mathrm{~cm}^{-1}$ (Shimakata et al. 1972); $25 \mu$ of microsomal sample was used in a final assay volume of $1.0 \mathrm{ml}$ which also contained $50 \mathrm{mM}$ Tris- $\mathrm{HCl} \mathrm{pH}$ 7.6, $0.3 \mathrm{~mm}$ NADPH (reduced nicotinamide dinucleotide phosphate), $60 \mu M$ cytochrome $c$ and $1 \mathrm{mMKCN}$. The reaction proper was started by the addition of NADPH. Total protein was measured by the method of Lowry et al. (1951).

Chemical analysís oí periwinkles. Digestive glands were used for PAH analysis and 2 pools of 5 animals each were taken per site or condition. The shells of the periwinkles were first cleaned with acetone, the tissues removed, damp-dried and stored at $-70{ }^{\circ} \mathrm{C}$ prior to analysis. PAH were extracted by steam distillation, 
analysed by high performance liquid chromatography and quantified in terms of total 2-ring $(2,3$-dimethylnaphthalene equivalents) and 3-ring (1-methylphenanthrene equivalents) compounds as described in Donkin \& Evans (1984).

Statistical treatment of data. Two or more groups of values were compared by 1 -way analysis of variance. In some cases log-transformation of the data was necessary to stabilize the variance.

\section{RESULTS}

Total microsomal protein yields of the digestive gland of Mytilus edulis were similar for all field sites and experimental conditions with the exception of the high dose condition which had a reduced yield; viz. in $\mathrm{mg}$ protein $\mathrm{g}^{-1}$ wet weight (means $\pm \mathrm{SE}$, number of samples in brackets), pooled field sites, $6.33 \pm 0.17$ (32); pooled C, L and M conditions, $6.15 \pm 0.30(24) ; \mathrm{H}$ condition, $4.92 \pm 0.19(8) ; p<0.05$ comparing $\mathrm{H}$ with $\mathrm{C}$ or field. Microsomal protein yields were similar for all

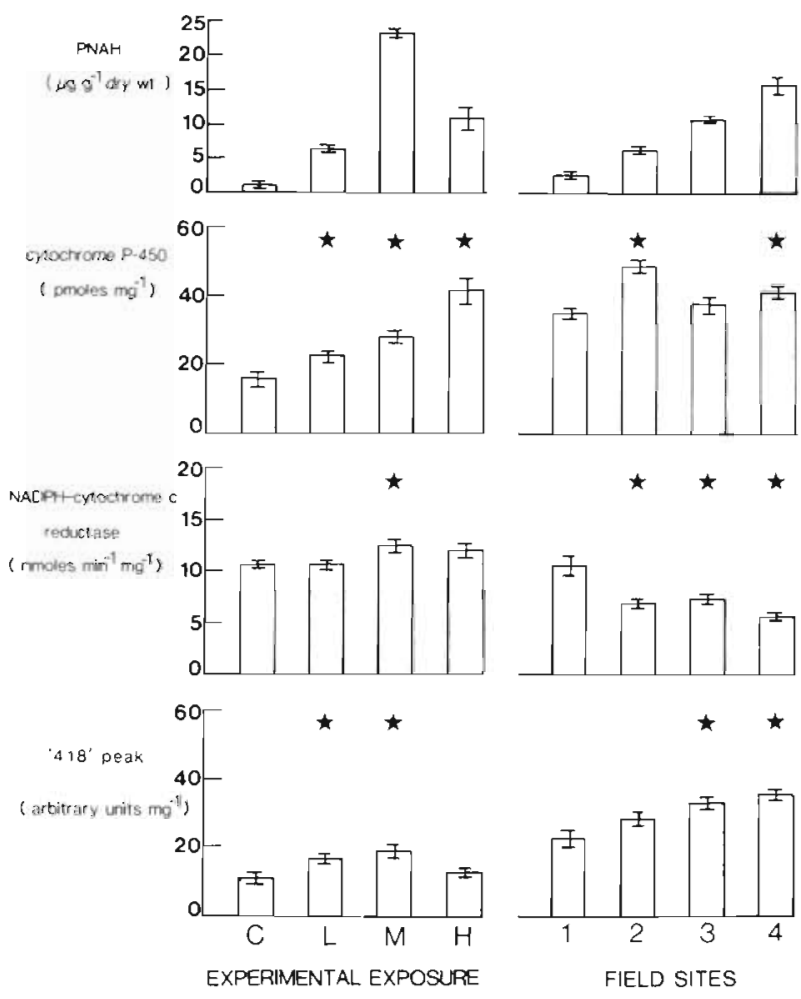

Fig. 1 Mytilus edulis. Responses of components of digestive gland microsomes to experimental exposures and at Langesundfjord sites (see text). Means $\pm \operatorname{SE}(n=8)$ for microsomal components, and means \pm semi-range $(n=2)$ for whole tissue PAH concentrations (latter from Klungsøyr et al. 1988). Significant differences in comparing field sites with the reference site (1), and experimental conditions with the control (C), indicated by ${ }^{\star} p<0.05$
Table 1. Mytilus edulis and Littorina littorea. Wavelength maximum $\left(\lambda_{\max }, \mathrm{nm}\right)$ of cytochrome P-450 of digestive gland microsomes of individuals from experimental exposures $\mathrm{C}, \mathrm{L}$, $\mathrm{M}, \mathrm{H}$ (see text) and all field sites in Langesundfjord; the latter data are pooled since no significant differences were observed. Means $\pm \operatorname{SE}(n=6$ or 8$)$

\begin{tabular}{|ccc|}
\hline Condition & M. edulis & L. littorea \\
\hline C & $452.0 \pm 0.2$ & $450.7 \pm 0.3$ \\
L & $451.9 \pm 0.3$ & $450.6 \pm 0.4$ \\
M & $450.5 \pm 0.5^{\circ}$ & $451.0 \pm 0.4$ \\
H & $448.3 \pm 0.1^{\circ}$ & $449.4 \pm 0.5^{+}$ \\
All sites & $449.5 \pm 0.4^{\circ}$ & $451.0 \pm 0.4$ \\
\multicolumn{3}{|c}{} \\
Significant differences in comparison with experimental \\
control indicated by ${ }^{+} p<0.10,{ }^{\circ} p<0.05$ \\
\hline
\end{tabular}

periwinkle groups, viz. pooled field sites, $6.23 \pm 0.18$ (24); pooled experimental conditions, $6.28 \pm 0.13$ (24). The microsomal preparations from field sites 2 and 3 were markedly different in appearance, being more particulate and 'gelatinous-like' and resuspending less readily than the other preparations.

Exposure to the diesel oil/copper mixture resulted in $\mathrm{PAH}$ accumulation in whole tissues of mussels, to higher tissue concentrations with increasing dose levels (Fig. 1). Mytilus edulis from the $\mathrm{H}$ condition were an exception, having lower PAH than for the $\mathrm{M}$ condition, presumably because of the much shorter time period of exposure of the former, i.e. about 3 compared with 15 wk. Copper accumulation also occurred (Abdullah \& Steffenak 1988). A gradient of PAH tissue contamination was evident in mussels through Field sites 1 to 4 (Fig. 1). The same was also seen for whole tissue polychlorobiphenyl (PCB) levels (Appendix 1, Table 9) and, to a lesser extent, for certain metals (Appendix 1, Table 16). The analysis of chemical contaminants in periwinkles was less comprehensive than for mussels, consisting only of total 2- and 3-ring PAH in the digestive gland (Fig. 2). These hydrocarbons accumulated with exposure of periwinkles to the diesel oil/copper mixture, and to increasing concentrations with increasing dose levels ( all periwinkle groups had the same exposure period of $15 \mathrm{wk}$ ). A steady gradient of $\mathrm{PAH}$ contamination was not evident in periwinkles through Langesundfjord Site 1 to 4 (by contrast with mussel concentrations), but the levels were higher at Sites 2, 3 and 4 than at Site 1 .

Results for digestive gland microsomal components of mussels are given in Fig. 1 and Table 1. Cytochrome P-450 content was elevated in a correlative fashion with exposure to increasing levels of the diesel oil/ copper mixture (Fig. 1) and the changes were accompanied by an increasing blue shift of the $\lambda_{\max }$ of cytochrome P-450 (Table 1). No clear gradient of change in 
cytochrome P-450 content was seen along the field gradient but the levels were significantly higher at Sites 2 and 4 than at Site 1 (Fig. 1). The $\lambda_{\max }$ of cytochrome P-450 was the same for all field sites, but was lower than that of the experimental control mussels which were collected from a field location near Solbergstrand; interestingly, the control mussels also had lower cytochrome P-450 content and lower total PAH than any of the Langesundfjord field sites, including Site 1. NADPH-cytochrome c reductase activity was slightly elevated at the higher doses of the diesel oil copper mixture but, conversely, showed a steady decline with increasing field contamination. In contrast, the ' 418 ' peak increased with both experimental exposure and increasing field contamination.

The results for the digestive gland microsomal components of Littorina littorea are given in Fig. 2 and Table 1. The responses of periwinkles to diesel oil/ copper exposure were qualitatively similar to those for mussels, viz. a steady increase in cytochrome P-450 content, a marked increase in NADPH-cytochrome $\mathrm{c}$ reductase activity at the higher dose conditions, a blue shift in the $\lambda_{\max }$ of cytochrome P-450 (Table 1) and an increase in the ' 418 ' peak in the high dose condition.

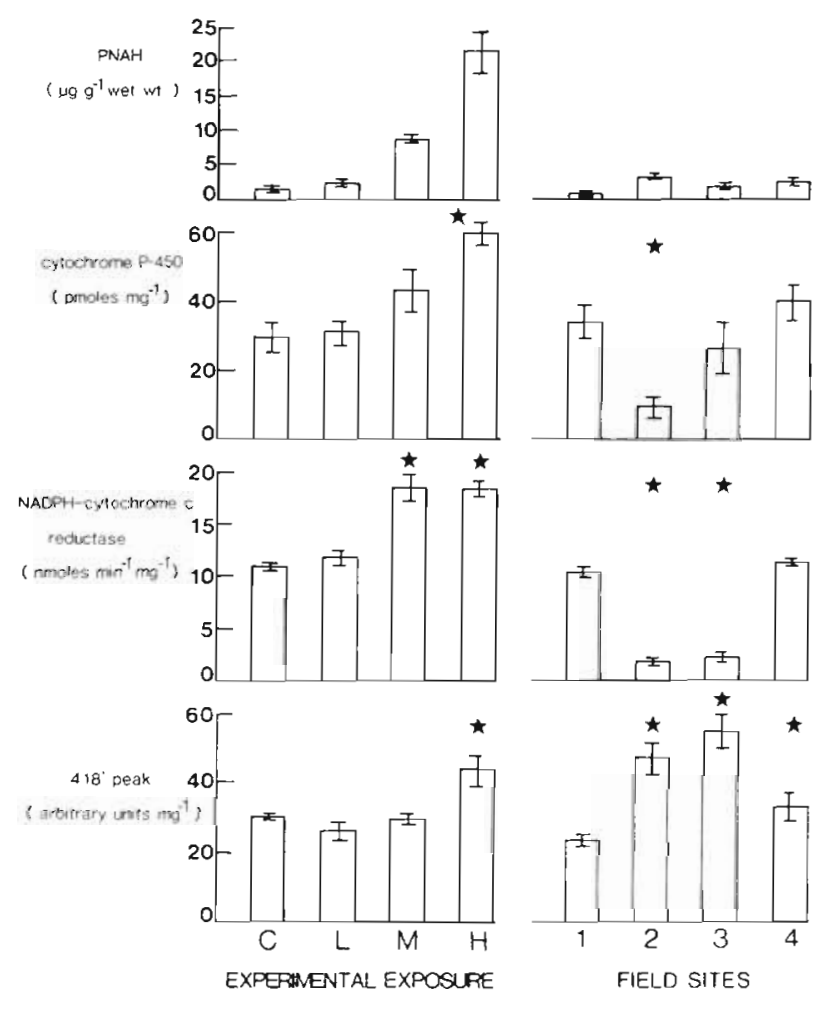

Fig. 2. Littorina littorea. Responses of components of digestive gland microsomes to experimental exposures and at Langesundfjord sites. Means $\pm \mathrm{SE}$ ( $n=6$ for experimental and 8 for field data) for microsomal components, and means \pm semi-range $(n=2)$ for 2-and 3-ring PAH in digestive gland (latter by the method of Donkin \& Evans 1984). ( $*$ ) Significance as for Fig. 1
The results for the field sites were very different than for mussels and characterised by the distinct nature of Sites 2 and 3 . These physically distinct microsomal preparations (see earlier) had very low cytochrome P450 contents and NADPH-cytochrome c reductase activities but very high ' 418 ' peaks (Fig. 2). Comparing Field sites 1 and 4 , the means of all the microsomal components were slightly elevated at 4 but this was only statistically significant for the '418' peak. Unlike the mussel results, the cytochrome P-450 content, P$450 \lambda_{\max }$ and measured PAH were similar in periwinkles from both Field site 1 and the control condition of the experimental exposure.

\section{DISCUSSION}

The responses of mussels Mytilus edulis and periwinkles Littorina littorea to the diesel oil/copper mixture were essentially the same as those observed in previous experiments when diesel oil alone was used (Livingstone et al. 1985, Livingstone 1987a), viz. cytochrome P-450 content and NADPH-cytochrome c reductase activity increased and the P-450 $\lambda_{\max }$ decreased, suggesting the synthesis of isoenzymes of cytochrome P-450. Subtle differences were seen from previous results, namely the progressive increase in cytochrome P-450 content in both mussels and periwinkles with increasing dosage exposure, and the threshold increase in NADPH-cytochrome $c$ reductase activity in periwinkles. However, it is clear from these observations and from the fact that cytochrome P-450 content was higher in high-dose mussels than mediumdose mussels but tissue PAH were lower (Fig. 1), that many pharmacokinetic and other factors will affect the relationship between dosage and biochemical response. No information is available on the effects of metals on the molluscan MFO system other than that Mytilus edulis exposed to about $600 \mathrm{ppb}$ cadmium in the water for 9 to $37 \mathrm{~d}$ showed only a slight decline or no change in the digestive gland microsomal $\mathrm{MFO}$ components or activities (Livingstone unpubl.). Given the results with diesel oil alone, and the fact that metals are not generally inducers of the MFO system (Snyder \& Remmer 1982), it seems unlikely that the uptake of copper was responsible for the observed elevations in cytochrome P-450 and NADPH-cytochrome c reductase activity.

Differences in the field, with the exception of periwinkles from Sites 2 and 3, were much less marked. Although there was no steady increase in cytochrome P-450 content in mussels through Sites 1 to 4 , the levels in mussels at 2 of the 3 polluted sites were higher than at Site 1 . In addition, the higher levels and lower $\lambda_{\max }$ of cytochrome P-450 of mussels from all Langesundfjord 
sites compared to experimental control mussels (the latter being from a different site) possibly suggests that mussels at Field site 1 may also have been induced; this may explain the relatively small differences between field sites. Cytochrome P-450 content, benzo(a)pyrene hydroxylase $(\mathrm{B}(\mathrm{a}) \mathrm{PH})$ and 7-ethoxyresorufin $\mathrm{O}$-deethylase (EROD) activities of flounder Platichthys flesus were also higher at Field site 1 than in experimental control animals (Addison \& Edwards 1988, Stegeman et al. 1988). However, in the case of mussels, this interpretation must be viewed with caution as the bivalves in the experimental exposure were also partially starved due to inadequate seston levels (Widdows \& Johnson 1988), and starvation could have had the effect of reducing microsomal MFO component levels.

The field results for periwinkles were dominated by the unusual differences at Sites 2 and 3, although there was some indication that microsomal components were slightly elevated at Site 4 compared to Site 1 . There are no supportive data to suggest the uniqueness of these 2 sites for periwinkles. The limited PAH data showed higher tissue levels at Sites 2 and 3 than at Site 1 but also higher levels at Site 4 ; if the percentage composition of total PAH in mussels is extrapolated to periwinkles then the same picture still emerges, viz. total 2- to 5-ring $\mathrm{PAH}$ in periwinkles in $\mu \mathrm{g} \mathrm{g}^{-1}$ wet weight, Site 1: 1.7, Site 2: 14.4, Site 3: 10.1, Site 4: 15.3 . Digestive gland lysosomal membrane stability, similarly, was reduced at Sites 2 and 3 compared to Site 1 but was also reduced at Site 4 (Moore 1988). Physiological measurements of scope for growth (Bakke 1988) did not identify Sites 2 and 3 as unusual for periwinkles but neither did they show a simple decline through Sites 1 to 4, as was the case for mussel scope for growth values (Widdows \& Johnson 1988).

The NADPH-cytochrome $c$ reductase assay in mammals is a measure of the activity of NADPH-cytochrome P-450 reductase (Masters \& Okita 1982) and the same is indicated in molluscs (Livingstone \& Farrar 1984 Livingstone et al. 1985). Increases in this enzyme activity in digestive gland microsomes with exposure to hydrocarbons have been observed in several bivalve species (Cardium edule, Moore et al. 1987b, and Mytilus edulis) and, in particular, gastropods (Thais haemastoma, Livingstone et al. 1986, and Littorina littorea), and appeared to offer potential in environmental monitoring. However, in contrast to the increases in NADPH-cytochrome $c$ reductase activity with increasing experimental exposure, only decreases in activity were observed with increasing tissue concentrations at the field sites. The molecular basis for this decline is unknown but it may be related to the fact that chemical contamination is well-established in Langesundfjord and a wide variety of lipophilic compounds are present that could possibly have interfered with enzyme function, for example by penetration into the membrane of the endoplasmic reticulum. The results may therefore indicate that responses in NADPH-cytochrome c reductase activity can only be used when monitoring is of chemical contamination in a relatively pristine area. However, more field data and basic understanding are required before a proper assessment can be made.

The ' 418 ' peak that occurs in the carbon monoxide difference spectrum of reduced cytochrome P-450 of digestive gland microsomes (Livingstone \& Farrar 1984) was quantified because it has been observed to increase with exposure of Mytilus edulis and Littorina littorea to hydrocarbons (Livingstone et al. 1985, Livingstone 1987a) and because it may be due to cytochrome P-420, the denatured or inactive form of cytochrome P-450. Equally well, however, it may be due to another haemoprotein, such as a peroxidase, and the molecular identity of the peak in molluscs is as yet unknown. Increases in the '418' peak were observed for both field and experimental samples from the workshop, particularly in field mussels, for which there was a strong correlation with the contaminant gradient. Of interest also were the high levels in periwinkles at Field sites 2 and 3 which corresponded to unusually low levels of cytochrome P-450 (Fig. 2). In field studies of the cockle Cardium edule, a population which had been impacted by an oil-spill, and which had experienced high mortality and was severely stressed showed very high levels of the ' 418 ' peak but no detectable cytochrome P-450 (Moore et al. 1987b). It is, therefore, tempting to speculate that the 418 peak may represent some breakdown product of the digestive gland microsomal system. It is also interesting in this respect to note that in the experimental exposure the levels of the '418' peak were lower in the high-dose mussels, which had been exposed for only $3 \mathrm{wk}$, than in the low or medium-dose mussels, which had been exposed for $15 \mathrm{wk}$ (Fig. 1), possibly suggesting the build-up of some microsomal component over time with exposure. Fundamental studies will be required to identify the molecular species responsible for the ' 418 ' peak but an application in environmental monitoring may be a possibility.

The application of biochemical responses to environmental monitoring and the development of specific indices of biological impact by organic pollution have been extensively discussed for molluscs (Livingstone 1984, 1985a, b, Livingstone et al. 1987, Moore et al. $1987 \mathrm{a}$ ). The problems of application are essentially 2 fold, the practical considerations of the detection of biochemical change against the background variability (the 'signal-to-noise ratio'), and the interpretation of such change. The differences in, for example, cytochrome P-450 content in Langesundfjord mussels were 
small, although this may have been related to the suggestion that mussels at all sites were induced by the contamination. However, the potential for change in measuring total cytochrome P-450, or cytochrome P450 reductase, is likely to be less than for an assay that is specific to a particular inducible cytochrome P-450 isoenzyme such as, for example, the EROD catalytic activity assay or cytochrome P-450 isoenzyme-specific antibodies studied in fish (Stegeman et al. 1986, Addison \& Edwards 1988, Stegeman et al. 1988). Whether such an assay exists for molluscs can only be resolved by fundamental studies but would obviously represent an improvement in sensitivity. Fundamental studies will also be required to interpret the biological significance to the mollusc of such observed differences. Although the evidence for the existence of the molluscan MFO system is substantial, from enzyme, metabolite and induction studies (Livingstone 1985a, 1987a, Stegeman 1985, Moore et al. 1987a), its functions in vivo are still a matter of debate (Stegeman 1985, Kurelec et al. 1986, Kurelec 1987, Livingstone 1987b, Suteau et al. 1988). The elucidation of the in vivo fate of organic xenobiotics, and the identification of monooxygenase activities that are responsive to organic xenobiotic exposure, which so far has been difficult to achieve in molluscs (Livingstone 1985a), are of paramount importance. For example, mono-oxygenase activities towards either foreign or endogenous substrates (fatty acids, steroids, prostaglandins) can be induced by exposure to organic xenobiotics (Kupfer 1982, Snyder \& Remmer 1982), and the catalytic specificities of the elevated cytochrome P-450 reported in this and other studies on molluscs are essentially unknown.

In summary, accepting the limitations of current understanding, it can be concluded from the elevated levels of cytochrome P-450 content, P-450 $\lambda_{\max }$ and possibly the ' 418 ' peak that mussels in Langesundfjord were impacted by organic pollution and increasingly so at the more contaminated sites. To this extent the results agree with those for the flounder Platichthys flesus (Addison \& Edwards 1988, Stegeman et al. 1988). However, nothing categoric can be said about the consequence in mussels for metabolism or activation of organic contaminants, or for mono-oxygenase endogenous metabolism. Impact of periwinkles in Langesundfjord, possibly at Site 4 but certainly at Sites 2 and 3. can also be concluded. However, in the absence of any supportive data, little can be said other than that the MFO system of periwinkles at Field sites 2 and 3 has been severely stressed but by factors unknown.

Acknowledgements. Periwinkle hydrocarbon analyses were carried out by S.V. Farrar: this is gratefully acknowledged.

\section{LITERATURE CITED}

Abdullah, M. I., Steffenak, I. (1988). The GEEP Workshop: trace metal analyses. Mar. Ecol. Prog. Ser. 46: 27-30

Addison, R. F., Edwards, A. J. (1988). Hepatic microsomal mono-oxygenase activity in flounder Platichthys Resus from polluted sites in Langesundfjord and from mesocosms experimentally dosed with diesel oil and copper. Mar Ecol. Prog. Ser. 46: 51-54

Bakke, T. (1988). Physiological energetics of Littorina littorea under combined pollutant stress in field and mesocosm studies. Mar. Ecol. Prog. Ser. 46: 123-128

Bakke, T., Follum, O. A., Moe, K. A., Sorensen, K. (1988). The GEEP Workshop: mesocosm exposures. Mar. Ecol. Prog Ser. $46 \cdot 13-18$

Davies, J. M., Bell, J. S., Houghton, C. (1984). A comparison of the levels of hepatic aryl hydrocarbon hydroxylase in fish caught close to and distant from North Sea oil fields. Mar. environ. Res. 14: 23-45

Donkin, P., Evans, S. V. (1984). Applications of steam distillation to the analysis of petroleum hydrocarbons in water and mussels (Mytilus edulis) from dosing experiments with crude oil. Anal. Chim. Acta 156: 207-219

Estabrook, R. W., Werringloer, J. (1978). The measurement of difference spectra: application to the cytochromes of microsomes. In: Fleischer, S., Packer, L. (eds.) Methods of enzymology, Vol. LII. Biomembranes: Part C: Biological oxidations, microsomal, cytochrome P-450, and other hemoprotein systems. Academic Press, New York, p. $212-220$

Follum, O. A., Moe, K. A. (1988). The GEEP Workshop: field sampling. Mar. Ecol. Prog. Ser, 46: 7-12

Gilewicz, M., Guillame, J. R., Carles, D., Leveau, M., Bertrand, J. C. (1984). Effects of petroleum hydrocarbons on the cytochrome P-450 content of the mollusc bivalve Mytilus galloprovincialis. Mar. Biol. 80: 155-159

Goldberg, E. D., Bowen, V T., Farrington, J. W., Harvey, G., Martin, J. H., Parker, P. L., Risebrough, R. W., Robertson E., Schneider, E., Gamble, E. (1978). The mussel watch Environ. Conserv. 5: 101-125

Klungsøyr, J., Wilhelmsen, S., Westrheim, K., Saetvedt, E. Palmork, K.H. (1988). The GEEP Workshop: organic chemical analyses. Mar. Ecol. Prog. Ser. 46: 19-26

Kupfer, D. (1982). Endogenous substrates of monooxygenases: fatty acids and prostaglandins. In: Schenkman J. B., Kupfer, D. (eds.) Hepatic cytochrome P-450 monooxygenase system. Pergamon Press, Oxford, p. 157-187

Kurelec, B. (1987). Reply to Comment on: 'Metabolic fate of aromatic amines in the mussel Mytilus galloprovincialis by B. Kurelec et al. (Mar. Biol. 91: 523-527, 1986)' by D. R. Livingstone. Mar. Biol. 94: 321-322

Kurelec, B., Britvic, S., Krca, S., Zahn, R. K. (1986). Metabolic fate of aromatic amines in the mussel Mytilus galloprovin cialis. Mar. Biol. 91: 523-527

Kurelec, B., Britvic, S., Rijavec, M., Muller, W. E. G., Zahn, R. K. (1977). Benzo(a)pyrene monooxygenase induction in marine fish - molecular response to oil pollution. Mar. Biol. 44: 211-216

Lee, R. F., Davies, J. M., Freeman, H. C., Ivanovici, A., Moore. M. N., Stegeman, J., Uthe, J. F. (1980). Biochemical techniques for monitoring biological effects of pollution in the sea. In: McIntyre, A. D., Pearce, J. B (eds.) Biological effects of marine poliution and the problems of monitoring Rapp P. - v. Reun. Cons. int. Explor Mer 179: 48-55

Livingstone, D. R. (1984). Biological differences in field populations of the common mussel Mytilus edulis L. exposed to 
hydrocarbons: some considerations of biochemical monitoring. In: Bolis, L., Zadunaisky, J., Gilles, R. (eds.) Toxins, drugs and pollutants in marine animals. SpringerVerlag, Berlin, p. 161-175

Livingstone, D. R. (1985a). Responses of the detoxication/ toxication enzyme system of molluscs to organic pollutants and xenobiotics. Mar Pollut. Bull. 16: 158-164

Livingstone, D. R. (1985b). Biochemical measurements. In: Bayne, B. L. et al. (eds.) The effects of stress and pollution on marine animals. Praeger Publishers, New York, p. $81-132$

Livingstone, D. R. (1987a). Seasonal responses to diesel oil and subsequent recovery of the cytochrome P-450 monooxygenase system in the common mussel, Mytilus edulis L., and the periwinkle, Littorina littorea L. Sci. Total Environ. 65: $3-20$

Livingstone, D. R. (1987b). Comment on: 'Metabolic fate of aromatic amines in the mussel Mytilus galloprovincialis' by Kurelec et al. (Mar. Biol. 91. 523-527, 1986). Mar. Biol. 94: $319-320$

Livingstone, D. R., Farrar, S. V. (1984). Tissue and subcellular distribution of enzyme activities of mixed-function oxygenase and benzo(a)pyrene metabolism in the common mussel Mytilus edulis L. Sci. Total Environ. 39: 209-235

Livingstone, D. R., Moore, M. N., Lowe, D. M., Nasci, C., Farrar, S. V. (1985). Responses of the cytochrome P-450 monooxygenase system to diesel oil in the common mussel, Mytilus edulis L., and the periwinkle, Littorina littorea L. Aquat. Toxicol. 7: 79-91

Livingstone, D. R., Moore, M. N., Widdows, J. (1987). Ecotoxicology: biological effects measurements on molluscs and their use in impact assessment. In: Salomons, W., Bayne, B. L., Duursma, E., Foerstner, U. (eds.) Pollution of the North Sea: an assessment. Springer-Verlag, Berlin (in press)

Livingstone, D. R., Stickle, W. B., Kapper, M., Wang, S. (1986). Microsomal detoxication enzyme responses of the marine snail, Thais haemastoma, to laboratory oil exposure. Bull. environ. Contam. Toxicol. 36: 843-850

Lowry, O. H., Rosebrough, N. J., Farr, A. L., Randall, R. J. (1951). Protein measurement with the Folin phenol reagent. J. biol. Chem. 193: 265-275

Masters, B. S. S., Okita, R. T. (1982). The history, properties and function of NADPH-cytochrome P-450 reductase. In: Schenkman, J. B., Kupfer, D. (eds.) Hepatic cytochrome P-450 monooxygenase system. Pergamon Press, Oxford, p $343-360$
Moore, M. N. (1988). Cytochemical responses of the lysosomal system and NADPH-ferrihemoprotein reductase in molluscan digestive cells to environmental and experimental exposure to xenobiotics. Mar. Ecol. Prog. Ser. 46: 81-89

Moore, M. N., Livingstone, D. R., Widdows, J. (1987a). Hydrocarbons in marine molluscs: biological effects and ecological consequences. In: Varanasi, U. (ed.) Metabolism of polynuclear aromatic hydrocarbons by aquatic organisms CRC Press Inc., Bocan Raton, Florida (in press)

Moore, M. N., Livingstone, D. R., Widdows, J., Lowe, D. M. Pipe, R. K. (1987b). Molecular, cellular and physiological effects of oil-derived hydrocarbons in molluscs and their use in impact assessment. Phil. Trans. R. Soc. Lond. B. (in press)

Moore, M. N., Pipe, R. K., Farrar, S. V. (1982). Lysosomal and microsomal responses to environmental factors in Littorina littorea from Sullom Voe. Mar. Pollut. Bull. 13: 340-345

Sato, R., Omura, T. (1978). Cytochrome P-450. Academic Press, New York

Shimakata, T., Mihara, V., Sato, R. (1972). Reconstitution of hepatic microsomal stearoyl-coenzyme A desaturase system from solubilized components. J. Biochem. 72: $1163-1174$

Snyder, R, Remmer, H. (1982). Classes of hepatic microsomal mixed function oxidase inducers. In: Schenkman, J. B., Kupfer, D. (eds.) Hepatic cytochrome P-450 monooxygenase system. Pergamon Press, Oxford, p. 227-268

Stegeman, J. J. (1985). Benzo[a]pyrene oxidation and microsomal enzyme activity in the mussel (Mytilus edulis) and other bivalve mollusc species from the Western North Atlantic. Mar. Biol. 89: 21-30

Stegeman, J. J., Kloepper-Sams, P. J., Farrington, J. W. (1986). Monooxygenase induction and chlorobiphenyls in the deep-sea fish Coryphaenoides armatus. Science 231: $1287-1289$

Stegeman, J. J., Woodin, B. R., Goksoyr, A. (1988). Apparent cytochrome P-450 induction as an indication of exposure to environmental chemicals in the flounder Platich thys flesus. Mar. Ecol. Prog. Ser. 46: 55-60

Suteau, P., Daubeze, M., Migaud, M. L., Narbonne, J. F (1988). PAH-metabolizing enzymes in whole mussels as biochemical tests for chemical pollution monitoring. Mar Ecol. Prog. Ser. 46: 45-49

Widdows, J., Johnson, D. (1988). Physiological energetics of Mytilus edulis: Scope for Growth. Mar Ecol. Prog. Ser. 46: $113-121$ 